\title{
P2RY2 wt Allele
}

National Cancer Institute

\section{Source}

National Cancer Institute. P2RY2 wt Allele. NCI Thesaurus. Code C112487.

Human P2RY2 wild-type allele is located within 11q13.5-q14.1 and is approximately $18 \mathrm{~kb}$ in length. This allele, which encodes P2Y purinoceptor 2 , is involved in both purine binding and signal transduction. 